\title{
Muddied Living: making home with dog companions
}

\author{
Abstract \\ Purpose
}

Focusing on everyday lives and relationships within the household, this paper suggests that the quality of 'home' is altered by the presence of animal companions. Conceptions of home as a haven have been critiqued on grounds of the elision of power relations, yet home has also been understood as a place of resistance to, and refuge from, an exploitative and exclusionary public world. Acknowledging differentiated relations of power and understanding homemaking as a process, this paper investigates the playing out of species relations within home space.

\section{Design/methodology/approach}

This paper draws on empirical material from a study of companion species in households and public spaces, deploying ethnographic material gained through extended observation and semi-structured and often mobile interviews with dog 'owners' in urban and rural contexts in the UK.

\section{Findings}

Dogs transform domestic space through muddying human lives. This process is twofold. First, life in posthumanist households problematizes boundaries between humans and other creatures in terms of relationships, behaviour and use of space. Second, muddied living involves breaching and maintaining domestic order. Muddied living is characterised by tension, power and compromise. Homes are posthuman not just by including non-human animals, but through elements of dog agency in how home is made.

\section{Originality}

Little has been written of 'home' within sociology, despite 'home' capturing a range of social practice. Sociologists examining human-animal companion relations have not considered how relations play out in home space. This paper investigates home as 
a shared space of multispecies interaction, making the case for a posthuman sociology of home.

\section{Keywords}

Companion species, dogs, home, power, space

\section{Introduction}

'Life is just muckier when you've got a dog' declared one of the interviewees in this study, and the notion of 'mucky' or 'muddy' lives underpins this paper. Living with animal companions in the home muddies life in two ways. First, there is the extra 'stuff' that dog companions bring in to domestic space in the West: hair, mud, plant matter, water, urine, vomit and faeces; and an array of disruptions to household hygiene and order are routine. Second, living with animal companions muddies human lives by calling into question the boundaries between humans and other house-dwelling creatures in terms of species, notions of family and home and the use of space.

Commencing with a discussion of the concept of posthumanism in relation to the home, this paper illustrates the notion of muddied living drawing on a study undertaken in two locations - East London and rural Leicestershire in the midlands of England. The resulting data is extensive, and this paper discusses data from one of its sources (ethnographic interviews) in relation to one of its themes - everyday life in the shared space of 'home'. The data suggests that the presence of a dog transforms a domestic space, with human interviewees reiterating a variation of the phrase 'a dog makes a house a home' because of the quality of specific relationships that muddy the clarity of human/nonhuman animal boundaries and shared practices and routines in a multispecies domestic space. 


\section{Posthuman home}

Sanders (1999: 2) notes there is 'conventional inattention' to human relationships with animal companions, leaving 'a considerable gap in the sociology of everyday life'; despite mundane practices and everyday relations being 'at the centre of human existence, the essence of who we are' (Pink, 2012: 143). This reflects the 'hard line' drawn in sociology between that which is human, and that which is 'animal' and thereby not of interest (Alger, 2003: 69). Yet almost half of UK households contain a cat or dog (Pet Food Manufacturers Association, 2014), with 23 per cent of UK households owning at least one dog (Pet Health Council, 2019). Across Europe there are an estimated 85 million dogs, 9 million in the UK (FEDIAF, 2018: 4-5, 8). This is associated with significant levels of household expenditure. In 2018, annual sales of 'pet food' was 21 billion Euros, with petrelated products and services accounting for a further 18.5 billion (FEDIAF, 2018: 5). Everyday lives, then, are often likely to be multispecies lives.

Posthumanist scholarship is concerned with accounting for the more-thanhuman constitution of the social and the co-constitutive character of human/nonhuman lives and relations. For Haraway (2008), important in understanding such co-constitution is embodied experience where companion species 'meet' as 'beings-in-encounter in the house, lab, field, zoo, park, office, prison, ocean, stadium, barn or factory' (2008: 5). Work on species encounters within the household has described the ways in which boundaries between humans and animals are porous (Mason and Tipper, 2008). Everyday practices of 'pet'-keeping involve the negotiation of human and non-human animal identities (Fox, 2006: 526). Survey data indicates animal companions are considered members of the family (Harris, 2011) while qualitative studies have found that this is due to the qualities of the relationships involved (Beck and Katcher, 1983: 59). The nature of the kinship bond may have different qualities to those between human members of the household (Walsh, 2009). For Fox (2008), animal companions are constructed as both family members, and as (almost) human in their 
individuality, yet on other occasions, they are defined by their instincts as 'animals'. Charles also finds that while animals can be human-like in their intimacies with family members, they are sometimes seen as being 'better at being family' than human members of a household because they provide affection without strings (2015:11). However, as Charles and Aull Davies (2008) note, such ambivalence suggests boundaries may maintained and breached consecutively, so that this does not necessarily involve the undermining of the human-animal divide. This work has been important in developing accounts of families and intimacies and the role of pet ownership ${ }^{\mathrm{i}}$ addressing the humancentrism in the wealth of literature on the sociology of families and family life.

This paper considers an even more marginalized sociological matter, that of home as a site of spatial relations in which humans and dogs interact. Sociologists have paid limited attention to the place that is 'home' and how it is used and shaped by occupants. Lasch's (1995) well-known account of the family ignored the spatial dynamics. Yet domestic relations are spatialized, they are enacted somewhere. Such spaces are varied cross-culturally, shaped by intersected forms of advantage and disadvantage and vary in material form from a suburban house, to a trailer or a street corner (Kusenbach and Paulsa, 2013). For Gieryn (2000: 264-5), who has insisted on 'a place for space' in sociology, the place of home varies in the way it is invested with meaning and value. The sociology of home is best described as 'nascent', surprisingly, given that so much of sociology is about home, whether that is the sociology of the family, community or migration (Anderson, Moore and Suski, 2016: 2-3); in addition to those of 'deviance', aging and the lifecycle and emotion (Kusenback and Paulsa, 2013: 2). 'Home' is certainly overdue some attention.

In developing a sociology of home sociologists have drawn on the humanistic tradition in geography where the understanding of home as a haven or space of refuge in which we emotionally invest, comes through strongly (Tuan, 1974, 1996). Such a place is not fixed, permanent, or rooted in notions of the 
authentic; rather, the constitution of space is always in the process of construction (Massey, 2005: 9). Home is understood as a 'center of meaning and a field of care' (Cresswell, 2004: 24) wherein people might be 'themselves'; having strong claims on the time, resources and emotions of its occupants. Sommerville (1992) suggests the meanings of home might be categorized as 'shelter' (physical security), 'hearth' (comfort), 'heart' (a site of love), 'privacy' (a boundaried space that occupiers control), roots (a source of identity), abode (a place of rest) and 'paradise' (an ideological construct fusing positive features of home). In trying to capture the extensive emotional ties conjured by the idea of 'home' and place, some deploy the notion of 'belonging' (Savage, Bagnall and Longhurst, 2005); while others reject this as effectively fixing home in a locality rather than understanding home as constantly in the making as people emplace themselves (Korac, 2009). Korac uses 'nesting' to connote dynamic processes of making home (2009: 31; also Ingold, 2012). In nesting together, humans and dogs invoke a number of Sommerville's practices and meanings of home, in particular 'heart' (practices of intimacy, love and care) and 'privacy' (a space for the expression of self, while also a space that humans control). Sommerville's notion of 'paradise' is too strong and I would propose that the multi-species home might be better understood as a heterotopic space, a fractured, multiple, partial glimpse of utopia at best (Foucault, 1986).

The home is also a matrix of heterogeneous social relations. Feminist scholarship has a legacy of critique of home as a privatized space in which oppressive and exploitative gendered practices and relations cohere and are relatively immune from public intervention. Rose (1993: 47-51) is rightly troubled by the universalism of Tuan and others, the lack of attendance to difference and the practices associated with it including reproductive labour, the costs of social reproduction, and danger of domestic violence (also de Lauretis, 1990; Hochschild, 1997). This lack of attention to gender, says Rose, marks 'home' as a masculinist place of desire (1993: 53). Not all feminists share such a view. The 
home can also be understood as a site of resistance, enabling a dignity and strength that black American women, for example, may have been denied in the public realm. The work of bell hooks (1990) is well known, reflecting on the home as a space of care and relative freedom in a racially exclusionary and often threatening public world. For hooks, home is both a refuge, and a place of empowerment. Similarly, the home might be a site of political resistance and emotive support for lesbian (and other non-heteronormative households) in a heterosexist public word (Valentine, 1993; Elwood, 2000), while fear of public space may for diverse women, render home a place of safety.

For many humanistic geographers, invested space such as 'home' is constituted reiteratively, made and remade through everyday practices. Each home makes its own world through the repetition of routines of sleeping, grooming, relaxing, cooking, eating and cleaning (Bowlby et al, 1997). The home is also a site of negotiation of spatial boundaries between household members. Sibley (1995) considers tensions between parents and children over the use of household space, which is both rule-bound and constantly negotiated. Children do not passively accept adult spatial boundaries within the home (Valentine, 1999). Within everyday spaces, the social is constituted as heterogeneous, relational and importantly 'lively' -- dynamic, shifting and emergent (Massey, 2005: 13, 55). A spatial lens pushes us towards the more-than-human - the place in which we dwell, the objects and (in the case of animal companions) subjects in which we emotionally invest.

Like children, despite communicative difficulties, dogs communicate within the context of home. In interviews, Sanders (1999: 14-15) found many accounts of people talking to dogs, and noted that they did not consider this 'selfspeech' but mutual communication. Accounts of dogs 'joining in' with rituals within the home suggest mutuality rather than human directed behavior (1999: 29-30). Apparently human objects and rituals of home are also shared as people 'share their meals with [animal companions], allow them to sleep on the bed, and 
to sit on the furniture, even to celebrate their birthdays' (Serpell, 1996: 74). Nonhuman animals specifically impact on the space of home. Gabb (2008) has suggested that being seen as a family member is reflected in the fact that private spaces within the Western home (such as bedrooms and bathrooms) are open to animal companions. Charles' (2016: 7) research indicates an absence of physical boundaries and the sharing of space, including beds. This has been described as a key characteristic of 'posthumanist' households (Power, 2008). In the case of some species, human accommodation may be profound. Smith (2003) shows how members of House Rabbit Societies radically modified the space of home by ...rabbit-proofing [which] meant that most of the furniture was made of metal, electrical cords were fastened behind furniture or covered in hard plastic or metal tubing, and protective wood strips were tacked onto wood baseboards (2003: 187)

Smith writes compellingly about the ways she and others attempt to accommodate peculiarly rabbit concepts of the management of household space in order to recognise rabbit as a full household member as opposed to a lesser being whose life will be largely determined by human wants. Long-term living with rabbits taught Smith that rabbits like to move along corridors at the edges of rooms and thus rabbits will attempt to move all unfixed furniture to the centre of a room. This, she says, 'changed forever the way I live in my house' (2003: 188). Things may be less dramatic in sharing space with dogs, but modifications there are, and also human resistance to the assertion of dog understandings of the appropriate use of space.

In previous work, I have suggested that humans are entangled in complex systemic relations of domination with non-human animals that I have called anthroparchy (Cudworth, 2011). The household is a site in which anthroparchal relations intersect with other systemic relations, of patriarchy, capitalism and so on. Within the home, dog companions are commodities, legally defined as property. Dogs are nearly always part of anthroparchal structures of reproduction - the product of the puppy breeding industry, often subject to its nexus of violence. As commodities, dogs can be passed from one household to another, abandoned to shelters or the street. The Western household is a key site of consumption, where the 
bodies of domesticated animals not considered 'pets' may be variously stored, prepared and consumed as food by both human occupants and companion cats, dogs and others (Cudworth, 2016). For many non-human creatures, a human home is a site of domination. As feminist animal studies scholarship has found, cats dogs and other animal companions may be implicated in forms of gendered domestic violence (Adams, 1995). Alternatively, 'pets' may be neglected, or treated with cruelty or violence in this privatized space, relatively immune from public view. Sutton (2019: 42) points out that much work in the field of 'pet studies' tends to render invisible the marked power relations between pets and their 'owners' and the practices of everyday domination associated with 'ownership' (with notable exceptions such as Pierce, 2016). Pet owners, along with their animal companions may also face discriminatory and exclusionary practices in relation to making home, as competitive private rental markets make it difficult for multispecies households to rent (Power, 2017).

Despite such restrictions, exclusions and forms of domination, as Haraway (2003) reminds us, other relations and practices are found; and this is the primary focus of this paper. In a human dominant public world, the relatively privatised site of home might also be a site of resistance where the eating of non-human animals is rejecteted; where relations of care and conviviality might enable the relative flourishing of humans and animal companions and where practices are negotiated and human boundaries challenged. Relational ties between humans and animal companions are established though everyday interaction in home space. Companion animals share everyday human routines, and routines are adapted to incorporate dog preferences (Power, 2008: 549); resulting in a "lived intersubjectivity" (Fox, 2006). In addition, the freedom of nonhuman animals in home space may be less restricted than in public space where dogs are subject to increasing forms of surveillance and control (Fox, 2017). Dogs also adapt the space of home. Philo and Wilbert (2000:13) suggest that there is a distinction between human constructions of 'animal space' and animals' constructions of space, which they refer to as 'beastly places'. These reflect 
animal understandings of the use of space and may be transgressive. The dogs in this study certainly attempted to etch their 'beastly' marks upon homespace.

It is in this sense of the home as multispecies, as also queering species boundaries and as enabling elements of anthroparchal resistance, that I understand the homes of the subjects in this study to be posthuman. Charles rightly suggests that close relations with animal companions are nothing new in the West, eschewing the use of 'posthuman' to describe the household (2015: 2). She suggests we simply acknowledge it is usual for humans and other animals to share domestic space in relationships of differing degrees of intimacy (2015: 8-9). As Ingold (2012: 173-4), points out, all creatures 'dwell' and while making home is a part of what makes us human, this may not be exclusively human ${ }^{\mathrm{ii}}$ for the 'house also has many and diverse animal inhabitants - more perhaps, than we are inclined to recognise' (2012: 187). Yet it is not enough to describe home as multispecies. My use of 'posthuman' is not to signal a new social form but to recognise social life as ever multispecies (Cudworth, 2011: 8-10); in addition, the quality of home and relations within it alters in its more-than-human constitution. The space of home is at the same time, dynamic while also routinized (Massey, 1994: 168). This is where this paper locates 'home' - in the intersection of power and its negotiation and of routine and shifting practices. In the processes of everyday routines and homemaking practices, the human-animal boundary is muddied. While the status of 'pet' implies that the boundary is maintained, even those humans who make stronger attempts to inscribe species hierarchy in the home breach it to some extent. The posthuman home is muddy, but to varied degrees, as the maintenance of species boundaries is fluid and partial. The data from this study suggests heterotopia is found in the everyday practices of multispecies living - posthuman home.

\section{Methods and data}


The material informing the discussion in the remainder of this paper is drawn from the semi-structured interviews investigating everyday lives with canine companions. Thirty-seven interviews were undertaken with people walking dogs on the marshes that form part of the Lea Valley Park in London. A second phase of fifteen interviews took place with people walking dogs around a village in rural Leicestershire. Similarly to other studies (Charles and Aull Davies, 2008; Fox, 2008) more women than men were found willing to participate. In part, this is because the majority of dog walkers observed in both locations were female, but is also likely to be because women are less reserved about speaking about their home lives or the qualities of their relationships. In the data below, both the locality and sex of respondents is given and where couples are interviewed, the sexuality.

Most of the interviews were mobile, accompanying informants walking with dogs on their usual route and asking questions along the way. Some interviewees chose other locations, such as pubs, cafés, their homes or occasionally, the author's home. Interviews chart the practices of 'responsible' dog guardians who walk dogs regularly and have close bonds with them. While some studies found that significant proportions of people did not allow animal companions into homes (24 per cent in the case of an Australian study, Franklin, 2006), all participants in this study shared homespace. Varner (2002) would characterise these households as having a relatively high level of inclusion, where human participants understand dogs as 'domestic partners' rather than 'companion animals' (with restriction in the home) or 'mere pets' (excluded from homespace for example, chained in yards). Thus this limited set of qualitative data does not provide an overview of the interactions of companion dogs in human homes, but considers a subset of inclusive human 'owners' and their spatial relations with dogs.

The data is co-constituted in that I worked in a research pack, accompanied by the dogs who share my home. Multispecies research resulted in certain peculiarities interview narratives are disjointed, interrupted by ball throwing, barking, dog play, greeting dogs and people who are 'not being interviewed'. When interviews took 
place in the home, there are dog interventions - barking, dreaming and attempting to sit on furniture or people. Interviewees occasionally address the dogs they live with for confirmation of what they say. The interview sample was shaped by the relationships of 'my' dogs, to others (both human and dog); yet their involvement was crucial - they secured legitimacy in the field and stimulated responses in interviews. Laughter features strongly in this data. Charles and Aull Davies (2008) considered that the use of laughter reflects the ambivalence associated with revealing too close a relationship with an animal. Some of the laughter here may be due to such embarrassment or may simply be that retelling stories of lives with dog companions makes people laugh. At which point, let us turn to what this data revealed about the muddy nature of lives lived with dog companions.

\section{Spatial negotiation}

For the vast majority of interviewees, dogs were allowed free reign of homespace; statements such as these were common:

He's allowed all over the home. (F, Leicestershire)

Everywhere, everywhere, everywhere - they've got the whole house to themselves (F, London)

Few attempts were made to restrict where dogs might go. For some, this was a point of principle enabling the free expression of dogs; as one put it: 'I wouldn't want a dog that was so regimented that it can only sit in a certain place' (F, London). For a third of interviewees however, dogs were excluded from certain areas (particularly bedrooms) or trained not to sit on the furniture. Here, the spatial arrangements of home were subject to the drawing and redrawing of boundaries for both humans and dogs. Sometimes this is for practical reasons, such as the size or the number of dogs:

Clearly he's quite a big dog [the dog is huge, a mixed mastiff/Great Dane], so he's not allowed up on the sofa because then there'd be no room for anybody else...He's not allowed in the dining room when we eat and there are doors that we can shut, exclude him from bits we don't want him to go; but he's pretty much got the run of the downstairs of the house. (M, London)

I couldn't afford to let three or four of them just take over the house (F, Leicestershire) For others, the literal messiness becomes too difficult to handle: 
I used to let them on the beds but I've stopped that now because it did take over and um feet marks and hair everywhere and well, you know, she'll [the larger dog] sit on yer bed and have a couple of farts and she'll tread in poo and walk all over your bed [laughing] (F, London)

Some considered that marking space for humans only is an issue of training and minimising 'unwanted' dog behaviour in the home, referring to their own research:

All the dog-training books said that you need a separate space, that it's not good for them to sleep in the bedroom or not be confined - they shouldn't have the whole space. So he has slept in the kitchen ever since he was say six months old. (F, London)

I have read lots of books that say that the top dog has to be the highest, higher, so if you sit here [on a chair], they would want to sit there [on the top of the back of the chair], they've got to be looking down on you... So up in the bedroom, if you give way, that then becomes their territory. We've never encouraged dogs upstairs or on to furniture. (F, Leicestershire) However, dogs -- as agential members of human households -- attempt to circumvent human plans for their containment, 'testing the boundaries' in homes where these exist. In this quote below, a man expresses his struggle for control over domestic space in the form of an imaginary conversation with one of the dogs he lives with:

Now since the [child stair] gate's been taken away - because I found I could put it in the garden then it could stop [name of dog] going up the bloody wall and into next door's garden - so immediately that was taken from the stairs she said "right, ok, I'm gonna go upstairs now"... then she took to sleeping on the beds upstairs. So the barricade I have to have to through if I come downstairs in the night [laughing], the business before I go to bed at night [laughing], it's a sort of a battle of wills you can have with dogs, well I have with this one anyway. So I thought "right, I'll put the ironing board on the sofa to stop her lying on the sofa", I have to put [his partner]'s sewing basket on the chair to stop her sitting on the chair then I have to get a folding chair and jam it between the stair rods on the stairs to stop her climbing up and lying on someone's bed, and I think "ok, now try and get in" [laughing hard]. (M, London)

A number of heterosexual and cohabiting female interviewees did indicate that they were more open to allowing free reign in the home than their partners:

I would allow her in every room but my partner doesn't want her in the bedroom. She loves coming in our bedroom. (F, London)

Dogs were allocated spaces for their exclusive use, and all had some kind of official 'bed'. Most interviewees considered it important for a dog's welfare that they were able to retreat to a space of their own. Below, a woman stresses the importance of the dog having an open crate in a spare room where he can escape from her human partner: 
F [Name of partner] just wanted to play with [name of dog] all the time. He couldn't bear to be separated from him, even for him to go to sleep, so he had to, you [directed at partner] had to train yourself really to give him some space. You did.

M [Shaking head in disagreement] Is this the same house we've been living in when you've had these dreams? Honestly, I ... [laughing]

F [Interrupting] He did, yes, he did! He was so overjoyed to have this dog that he just couldn't bear to be separated from him, right from day one [laughing]. (Heterosexual couple, Leicestershire)

The use of home space therefore, is open to dogs to differing degrees, although boundaries are likely to be flexible over time and subject to negotiation.

\section{Beastly place}

Despite the relative power of humans in the home, the agential being of dogs asserts itself in shaping place. In her moving discussion of the end of life of a much-loved companion, Pierce (2012) suggests that caring for an aging dog places intense demands as we adapt our homes and routines significantly, and put up with large amounts of mess. After the death of her dog, Pierce reflects that he has also

etched himself into our house, through the stitched up scars in the couches, the extra tall fences, the scratches in the doorframes, and the fact that every blanket and bedspread has holes...And he has etched himself into my heart as fully and painfully as any creature ever has (2010: 224)

The destruction of furnishings was an occupational hazard of living with dogs for those who raised this as an issue. Tales of 'bad' behaviour are mitigated. The ultimate mitigation is love, often expressed through tales of canine improvement or human adaptation:

Up until the age of about two, he chewed through two settees, a kitchen wall, he rounded off all my kitchen cupboards [cupboard doors] but he grew out of that [...] he's the perfect dog now. (F, London)

Alternatively, mitigation takes the form of resignation and concealing damage. There is a literal covering up of the household damage caused by dogs, and a metaphorical covering up whereby this is described as behaviour which is 'grown out of', or was/is expected to be temporary:

Our couch, well, it's been repaired once, but it's completely wrecked. You know, structurally its fine but, you know, the cushions and seat and stuff -- we've put a blanket over it now... And with the first cushion that was trashed I got annoyed, but now, well [pause] you know. (F, London) 
[Name of $\operatorname{dog}$ ] used to strip the wallpaper off and then [name of another dog] started doing that. And he's eaten nearly the whole of my big window seat...he's ripped all the leather and pulled all the stuffing out so there's a big hole...so I keep putting a blanket over it now. (F, Leicestershire)

Here then, we find human apology and perhaps embarrassment for the ways in which dogs are successful in making place beastly; but also both elements of toleration of dogs remaking space in the manner of their own choosing.

Another way in which dogs assert themselves is by considering what is supposed to be for humans to be something for them. In most cases, this involves food, but occasionally clothing and footwear. Tales of destruction are laughed away, and often caveats about things being left 'out' serve to excuse destructive behaviour. These stories are found retrospectively amusing with people keen to tell them:

Well, the Staffie [Staffordshire terrier, rescued] from out of the canal, he could open the fridge. And he'd do it while you were there [...] like he'd be standing there and [impersonating dog] "move along", pushing you out the way. I used to do quite a bit of catering and she [another dog] had off the side [kitchen worktop] 72 vol-au-vents, 72 [laughs]! (F, Leicestershire)

He stole 12 onion bhaji's and 12 samosa's - frozen -- from on top of the cooker. I was laying the table, for a meal, and I heard this big clang -- and it was on the back of the cooker as well - a big clang on the floor. By the time I got in there, nothing left, he'd eaten the whole lot. (F, Leicestershire)

Dogs also have their own sense of what makes a pleasantly smelling home and a desirably perfumed body that are often starkly at odds with human notions:

Rolling in fox poo, eating it, stinking out the car. When he trumps at home we all blame each other, but it's 'im, lying on the floor [laughing]...And they look at the person nearest them as well. (F, London)

[Name of dog] does have the habit of eating rather disgusting things on occasions and feeling somewhat the worse for it and sort of deciding to retch them up in the middle of the living room which is just so vile. I've actually...put rubber gloves on and brushed her teeth 'cos, you know, rank breath and everything, you know, "you're staying there! Stay out there!" [directed at dog, laughing]. (M, London)

I found he wasn't very good with being house-trained with his wee, it has to be said. At the time I just remember weeping and constantly mopping and just thinking "oh my god, oh my god, this is awful" [laughing]. (F, London)

Some compared the more 'disgusting' aspects of embodied living with other animals to caring for children: 
It didn't feel like a big deal to take on responsibility of a dog; I've sort of been bringing up children for the last thirty years more or less. I've got sort of stepsons as well as grandchildren and things... mopping up after other people's mess is, well, I've done it for so long it doesn't really matter whether it's a human or a [pause] or an animal. (M, London)

A lot of people say I'm not having a dog because I've got to pick the poo up, but I've had two children, I've done nappies, and you know, you can wash your hands. (F, Leicestershire) Damage to the house and 'disgusting habits' were seen to be inconvenient, time consuming or expensive but no one considered this to be the most negative aspect of home lives shared with dog companions.

It was the impact of human working lives that was the 'worst thing' about living with a dog (and was sometimes used to explain destructive behaviour). It is interesting to note that other studies have found that one of the main reasons people have given as to why they do not have a dog companion is that they are working and/or do not have enough time for a dog, rather than not 'liking' dogs (Westgarth et al, 2007: 2). Most human interviewees were conscious of, and sometimes expressed guilt about, the length of time dogs may be left home alone and could become 'bored' or 'lonely'. The most popular answer to the question 'what would make your life easier living with a dog?' was a version of 'not having to go to work'. The second most popular answer involved 'not living somewhere where it rains all the time' (F., London), and this has direct bearing on living with mud.

The majority of interviewees in this study were women, and only one of the men mentioned the presence of hair or mud on the home, or its impact on reproductive labour. Most women however, raised the cleanliness of the house as an issue, with all agreeing that 'you have to clean a bit more because obviously they make a lot of mess' (F, London). There were distinctive ways in which the 'mess' associated with dogs is discussed. There were stories of rebellion and a positive rejection of being 'house proud', often related to discussion of relationships with parents and a desire to be different:

When we go [to visit parents] with the dogs, Mum tries her hardest not to care about the hair and stuff...She puts down these sheets and they sit, but not quite on the sheet. And she says "why don't they sit on that sheet?" and I say “well they're dogs Mum, you can't expect that"...We're not house proud at all. (F, London) 
My Mum didn't like cats and she didn't want a dog. I think it was the hair and the dirt -- very house proud. I think that's why I like having lots of animals and hair everywhere, it's a little bit of my rebellion [laughing] against order and tidiness. (F, London)

My Mum and Dad would never let me have a dog because they were very house proud... and I think, in this day and age, they wouldn't have had children, you know, very selfish. We always had cats and we lived in the countryside but we could never have a dog, never ever have a dog. So as soon as we got married the first thing I had was a dog. (F, Leicestershire) For others, living with a dog results alters their ideas about the cleanliness of home space:

I was a little bit house proud before I had him, a bit particular, but that's gone ...you just accept that you're going to have muddy footprints and you know you're going to have bracken brought in and you're going to have muddy paw prints within a day of cleaning your windows, you know, but it doesn't matter, I mean, it doesn't matter. I'd prefer to have [name of dog] than a clean and tidy house all the time [laughs] (F, Leicestershire)

Mud and various other forms of 'dirt' were inevitably associated with living with dogs. Most female interviewees mentioned paw prints, splash marks on walls and that their homes were sometimes a bit more 'smelly' than they would be without a dog. Such observations were accompanied by accommodating comments such as 'that's what they do and that doesn't really bother me' or that people simply have to make extra time for cleaning the $\operatorname{dog}(\mathrm{s})$, themselves and household space after wet walks. Detailed stories of the management of dirt within the home are often followed by matter-of-fact statements about the acceptance of muddier home life:

if she's really, really muddy and wet I could put her in the bath and give her a shower which she actually quite likes...I do have a blanket on the sofa so she can go on there, but she doesn't have to. If she goes on where there's not a blanket I don't tell her off. But that's just one of those things that I came to terms with as soon as I got a dog. I don't want to have a dog and then say "oh you can't go here" and "you can't go there"; I've got a dog and I just deal with it. (F, London)

A concern for a number of interviewees in both study sites was that people adopting dogs perhaps do not always realise the amount of work and time this is likely to involve -- 'how life-changing it can be' (F, Leicestershire).

\section{Dirty pleasures of co-sleeping}


Over half of the interviewees shared bedrooms or beds with dogs. 'Sleeping with your Jack Russell [terrier], what's not to love?' asked one, and most people did seem to enjoy co-sleeping, even when space might be in short supply:

the boys [dogs] all sleep on the bed [interviewer - all 3 of them?] Yep.

[Partner interjecting] Yep, the three boys, always on the bed, fighting to get in. (Lesbian couple, London)

Co-sleepers told of a dog's ability to acquire and maintain space, and to move considerably larger and heavier sleeping human bodies:

I've got a king size bed and he takes up most of it so I usually find that I'm across the top or wedged into a really small bit of the bed and he's stretched out over the whole thing and he takes up a surprising amount of space for a small dog [meaning slim, a whippet lurcher]. But it really amazes me that he's so heavy as well so I can't really move him either; I have to actually kind of wake him up and get him off the bed just so that I can move (F, London) For most, there is some guilt attached to sleeping with dogs, perhaps deriving from reading books on dog training (which invariably advise against this). A number of interviewees describe co-sleeping as a guilty pleasure, aware that other dog owners or those not living with dogs would find co-sleeping difficult to understand:

He mostly sleeps with me which I always said that I wasn't going to do but then it's just too tempting, you know, he comes in for a cuddle in the morning or something. It's really nice. I have a cup of tea and a cuddle on a Saturday morning and take him out for his walk. (F, London)

People say "ugh that's disgusting", you know, but I think "what are they going on about?" [laughing]. I would rather have some dogs in my bed than some of my friends, you know, with the mess they make and the carnage they cause! (F, London)

M When people go "What? You let them [the cat and the dog] sleep on your bed?" they look at you in such a disgusted way.

F But it's not like we make him [the dog], it's like you know $\mathrm{M}$ [interrupting] He chooses to, it's that thing of being close, it's like pack animals would sleep together...He sleeps between us, on his back, snoring his head off. (Heterosexual couple, Leicestershire)

Some humans were resistant to sharing a bedroom with a dog, let alone a bed, but another common tale is one of a dog's ability to be persistent. A number of interviewees commented that they had not initially intended to share their bed. For a number of those co-sleeping, the notion that dog sociability needs to be taken into account comes through strongly - as the male interviewee above suggests. Below, a woman has specifically been given 'expert' advice on pack co-sleeping: 
He barked and howled for a year every night when I put him to bed, and he would go all night without stopping. He did not stop unless I went downstairs and sat with him. So I used to go downstairs because I couldn't stand it and I was worried about the neighbours...I just thought "I can't do this anymore" and I'd spoken to a lady in Germany on the Schnauzer website and she said "the worst thing you could have done was try to make him sleep on his own"; she said "they like company, they like being with you, they feel it's their job" (F, Leicestershire)

Finally, it is worth noting that in the London sample where a number of lesbian couples and quite a few single women were interviewed, that these women were likely to allow dogs in bedrooms and beds. Among heterosexual interviewees, there was also 'illicit' co-sleeping by women if their partner was away. The tolerance of people in both study sites to sharing bedroom or bed space with dog companions was an unanticipated finding.

\section{Home is where the dog is}

A number of interviewees discussed concerns about dogs in the home. For some, this involved anxieties past or present with renting properties with dogs, and where people were able to live was sometimes influenced by their decision to live with companion dogs. Many made the point that home or family was not complete without a dog and both those with and without children of considered that it positive for children raised in households with dogs. All made some comment about the quality of home altered in significant ways by the presence of a dog. Many interviews contained a version of phrases such as 'having a dog makes a house a bit more homely' and the presence of 'somebody who's always pleased to see you'. Most commented on the way in which dogs greet them returning to the home and the company of a dog in the house:

She's always here, you know, even if you're in the house on your own, you've got somebody. I talk to her all the time...I just love having her really. (F, London)

When you come home...he's so pleased and so excited to see you that even if you've had the most rubbish day that you can imagine you just think "ah, it's great to be home". (F, Leicestershire)

A house without a dog is seen as a more 'empty' or 'lonely' space

In the short breaks that we've not had a dog, you get home from work and there's a quiet, empty house. (F, Leicestershire) 
The house would be very empty without a dog I think because it's just somebody...an unconditional love, you know, they never ask questions...they're always there and even if you have a bad day, the dog is not going to question you, or make it worse [laughs] (F, London)

One couple described the 'gaps' between dogs and after the death of a dog as one in which they 'ate out, stayed out late and kept going away just because we really didn't want to go home'.

Most people talked to the dogs they lived with, and as Sanders found, they understood this as a genuine exchange - dogs are both company and companions because they share communication in homespace:

I get more sense out of the dogs than I do my husband [laughs]...They know what I'm doing, don't you [directed to the dogs]? You know where I'm going, yes. (F, Leicestershire)

I think it's a really lovely thing to have a dog in the house. You can stroke them and you know they follow you around and look at you and they understand everything, they do, they absolutely understand. (F, London)

Dogs are a tactile physical presence. Female interviewees in particular talked of the pleasures of petting a dog. All interviewees engaged in shared practices - for example, watching television with dogs, dogs 'helping' with gardening or in one case, meditating. Some described specific games they had developed in the home with their dog:

We call it 'stair-ball' because she sits at the top of the stairs and tosses her ball down or her toy, whatever it is, and barks until you throw it back upstairs. (F, London) Some referred to a dog's feelings about their 'pack', emphasising that dogs seemed to me more relaxed or 'happy' when all the members of the household were together. Dogs also seem to have a mediating presence within the home

It's that third ear...it helps with any tension at all in the house, you can communicate with the dog [dog barks] (F, Leicestershire)

[Name of dog] hates it if we are arguing in the house. Obviously that doesn't happen very often [laughing]. If we are shouting he really hates it, he will go from one [person] to the other and do a little bark, yep he hates it and looks quite like [impersonating the dog] "Oh my god, please sort it out". It just adds another dimension doesn't it? (F, London)

The presence of a dog can help smooth tensions because the dog can be a conduit for speech between humans, have a role of confidant or actively mediate. Many claimed that the presence of dogs was 'relaxing', and perhaps this ability of dogs to live in 
the present and enjoy the moment is what enables them to intervene in human interactions and exert a calming influence.

These aspects are important cues not only in ascertaining the close relations people have with their 'pets' and the interactions they have, but also the discrepancies of power. The idea that the dog at home waits for humans - to provide attention, affection, company and entertainment suggests that the overwhelming beneficiaries of this relationship are human owners. However, the material described here paints a partial picture. As we saw above, dog owners are highly concerned about the impact of their working lives on the life of the dog who lives with them. Elsewhere I have noted that owners considerably adapt working times and patterns, holiday and leisure pursuits (beyond 'dog walking') to ensure a fuller and more varied life for the dogs of their heart (Cudworth, 2011: 158-60). Thus while it is difficult to conceptualise 'pet' ownership as anything else but an exercise of dominatory power, the humans in this study were aware of the unfree condition of dogs and concerned to make home in ways that reflected their understandings of dog interests.

\section{Concluding thoughts}

Life's a lot easier without them because you haven't got to be [vacuuming] or sweeping or mopping or cleaning and also you've got time on your hands because you're not out a couple of hours a day dog walking. But I think it's emptier. (F, Leicestershire)

This woman's speech speeds up as she catalogues the work involved in living with a dog until she shifts tempo to conclude that life with dog-related labour is life less empty. An interesting question for further investigation would be the extent to which this animal-related work can be conceptualised in terms of feminist understandings of reproductive labour. There were gender differences in terms of concern for the work involved in caring for dogs and posthuman homes, yet women were more likely to allow dogs free reign of domestic space and to share intimate space with them. 
While some homes allow free movement, others police the human distinction through spatial boundary marking. However, as active shapers of home, dogs assert their presence across the domestic space - stealing food from kitchens and inches from beds. Many dogs attempted to make homespaces beastly places, incurring increased levels of cleaning, washing, drains on time, and damaged property. Interviewees were clear that lives with dogs involved work and effort, and many of the problems faced were mitigated through physical alteration to the home or shifting human perspective. The posthuman home for my human participants is a space in which dogs contest boundaries, both physical and emotional and where everyday practices and relations are muddied. In the breaching and reinscribing of the boundaries of species and of domestic order, there is lived intersubjectivity, played out in multi-species routine and home making practices, intra-species communication and the cementing of affective ties.

Within stories of the shared lives of 'responsible' dog guardians however, power makes its presence felt, for example in the uneasiness many feel about the status and lives of animal companions often left home for long hours. Perhaps this unease about the vulnerability of dogs in a human world prompts the array of caveats that cover the challenges of posthuman home life. In this way, micro level data -- stories of mundane and routine lives lived with dog companions -- fold in to the wider social structures and practices of human relations with companion dogs. The posthuman home is not a space of equality but of human domination and for some domestic animals captive in the home, it is a place of deprivation or violence. Yet the dogs in this study were, as Varner suggests, mostly domestic partners, otherwise animal companions and never 'mere pets'. There are degrees of intimacy present but every interviewee had something to say of how lives, households and the experience of 'home' is altered by the presence of dogs and how their relationships were with particular dogs as individuals.

There is not purity of species in the posthuman home but what might be described as a 'mongrel domestic' (Cudworth and Jensen, 2016) in which human(s) 
and $\operatorname{dog}(\mathrm{s})$ come together in various degrees of spatial, physical and emotional intimacy. In muddying dwelling spaces and domestic relationships, dog companions are active in making a different kind of home. Despite anthroparchy in the public world and abuse and neglect in many homes wherein 'pets' are kept, the posthuman home might be, at least to some degree, a 'haven in a heartless world'. For both human and canine dwellers, home can be a place where love and care happen and dogs express self more fully as a lively presence attempting to shape their place. This study, then, catches glimpses of heterotopia in the spaces of muddied living.

\section{References}

Adams, C. J. (1995), “Woman battering and harm to animals" in C. J. Adams and J. Donovan (eds) Animals and Women: Feminist Theoretical Explorations, Durham, N. Carolina: Duke University Press.

Alger, J.M. (2003), "Drawing the line”, International Journal of Sociology and Social Policy, Vol.23 No.3, pp.69-93.

Anderson, G., Moore, J. and Suski, L. (2016), “Introduction: for a sociology of home in Canada", in G. Anderson, J. Moore and L. Suski (eds) Sociology of Home: Belonging, Community and Place in the Canadian context, Toronto: Canadian Scholars Press.

Beck, A. and Katcher, A. (1983), Between Pets and People, New York: Putnam's. Bowlby, S., Gregory, S. and McKie, L. (1997) “'Doing home': Patriarchy, caring and space", Womens Studies International Forum, Vol.20 No.3, pp.343-350.

Charles, N. and Aull Davis, C. (2008), "My family and other animals: pets as kin", Sociological Research Online Vol.15 No.5, http://socresonline.org.uk/13/3/4.html

Charles, N. (2014), “'Animals just love you as you are'”: experiencing kinship across the species barrier", Sociology, Vol.48, pp.715-730.

Charles, N. (2016), "Post-human families? Dog-human relations in the domestic Sphere", Sociological Research Online available at http://www.socresonline.org.uk/21/3/8.html. 
Cresswell, T. (2004), Place: a short introduction. Oxford: Blackwell.

Cudworth, E. (2011), Social Lives with Other Animals: Tales of sex, death and love. Basingstoke: Palgrave.

Cudworth, E. (2016), “On ambivalence and resistance: carnism and diet in multispecies households", in A. Potts (ed.) Critical Perspectives on Meat Culture. Brill, pp.222-242.

Cudworth, E. and Jensen, T. (2016), "Puppy Love? Companion Animals in the

Media", in N. Almiron, M.C. Cole and C.P. Freeman (eds) Critical Animal and Media Studies: Communication for Nonhuman Animal Advocacy, Routledge, pp. 185-200.

De Lauretis, T. (1990), “Eccentric subjects: Feminist theory and historical Consciousness". Feminist Studies, Vol.6 No.1, pp.115-150.

Elwood, S. (2000) “Lesbian living spaces: multiple meanings of home”, Journal of Lesbian Studies, Vol.4, pp.11-28.

FEDIAF (The European Pet Food Industrial Federation) (2018), Facts and Figures 2018, Brussels: FEDIAF. Available at www.fediaf.org, accessed $14^{\text {th }}$ August 2019.

Foucault, M. (1986), ‘Of Other Spaces' Diacritics, Spring, pp.22-7.

Fox, R. (2006), “Animal behaviours, post-human lives: Everyday negotiations of the animal - human divide in pet-keeping", Social and Cultural Geography, Vol.7 No.4, pp.525- 537.

Fox, R. (2017) “Intimate cartographies: Creating place with companion animals”, in J. Bull, T. Holmberg and C. Asberg (eds) Animal Places: Lively cartographies of human-animal relations. Abingdon, Oxon.: Routledge: pp. 85-104.

Franklin, A. (2006), Animal Nation, University of New South Wales Press.

Gabb, J. (2008), Researching Intimacy in Families, Basingstoke: Palgrave Macmillan. Gieryn, T. F. (2000), “A space for place in sociology”, Annual Review of Sociology, Vol.26 No.1, pp.463-496. 
Haraway, D. (2003), The Companion Species Manifesto: dogs, species and significant Otherness, Chicago: Prickly Paradigm Press.

Haraway, D. J. (2008), When Species Meet, Minneapolis, Mn.: University of Minnesota Press.

Harris (2011), "Pets are really members of the family", Harris poll. Available at: hhttp://www.harrisinteractive.com/NewsRoom/HarrisPolls/tabid/447/clt/Read Custom\%20Default/mid/1508/ArticleId/814/Default.aspx.

hooks, b. (1990), Yearning: Race, gender and cultural politics, Boston, MA.: Beacon Press. Hoschild, A. (1997), The Ties that Bind: When work becomes home and home becomes work, New York: Metropolitan Books.

Ingold, T. (2012), The Perception of the Environment: Essays on livelihood, dwelling and Skill, London: Routledge.

Irvine, L. and Cilia, L. (2017), “More-than-human families: Pets, people and practices in multispecies households", Sociology Compass, Vol.11 No.2.

Korac, M. (2009), Remaking Home: Reconstructing life, place and identity in Rome and Amsterdam, New York and Oxford: Berghahn Books.

Kusenback, M. and Paulsa, K. E. (eds) (2013), Home: International perspectives on culture, identity and belonging, New York: Peter Laing.

Lasch, C. (1995), Haven in a Heartless World: the family besieged. [first published in 1977] London: W.W. Norton and Co.

Massey, D. (1994), Space, Place and Gender. Cambridge: Polity.

Massey, D. (1995), For Space. Cambridge: Polity.

Mason, J. and Tipper, B. (2008), “Being related: How children define and create Kinship". Childhood, Vol.15 no.4, pp.441-460.

Pet Food Manufacturers Association (PFMA) (2014), “Pet population 2013”, available at www.pfma.org.uk/petpopulation (accessed 3 October, 2014).

Pet Health Council (2019), "People and pets" available at http://www.pethealthcouncil.co.uk/people-and-pets (accessed 14 August, 2019). 
Philo, C. and Wilbert, C. (eds) (2000), Animal Spaces, Beastly Places: New geographies of human-animal relations. London and New York: Routledge.

Pierce, J. (2012), The Last Walk: Reflections on our pets at the end of their lives. Chicago: University of Chicago Press.

Pierce, J. (2016), Run, Spot, run: the ethics of keeping pets. Chicago: University of Chicago Press.

Pink, S. (2012), Situating Everyday Life. London: Sage.

Power, E. (2008), "Furry families: Making a human-dog family through home”, Social and Cultural Geography, Vol.9 no.5, pp.535-55.

Power, E.R. (2017), “Renting with pets: a pathway to housing insecurity?” Housing Studies, vol.32 No.3, pp.336-360.

Rose, G. (1993), Feminism and Geography: the limits of Geographical knowledge. Cambridge: Polity.

Sanders, C. R. (1999), Understanding dogs: Living and working with canine companions. Philadelphia: Temple University Press.

Savage, M., Bagnall, G. and Longhurst, B. (2005), Globalization and Belonging: The Suburbanization of Identity. London: Sage.

Serpell, J. (1996), In the Company of Animals, Cambridge: Cambridge University Press.

Sibley, D. (1995), “Families and domestic routines: constructing the boundaries of childhood", in Pile, S. and Thrift, N. (eds) Mapping the subject: Cultural Geographies of transformation, London: Routledge.

Sommerville, P. (1992), "Homelessness and the meaning of home: rooflessness or Rootlessness", International Journal of Urban and Regional Research, Vol.1, pp.529-39.

Smith, J. A. (2003), “Beyond dominance and affection: Living with rabbits in Post-humanist households", Society and Animals, Vol.11 No.2, pp.182-197.

Sutton, Z. (2019), Choreographing human-companion animal relationships, unpublished $\mathrm{PhD}$ thesis, Flinders University, Australia.

Tuan, Y-F. (1974), Topophilia: A study of environmental perception, attitudes and values, 
Englewood Cliffs, N.J.: Prentice Hall.

Tuan, Y-F. (1996), Cosmos and Hearth: A cosmopolitan viewpoint, Minneapolis: University of Minnesota Press.

Valentine, G. (1993), “(Hetero)sexing space: lesbian perceptions and experiences of everyday spaces", Environment and Planning D: Society and Space, Vol. 11, pp.395-413.

Valentine, G. (1999), "'Oh please Mum, Oh please Dad': negotiating children's spatial boundaries", in McKie, L., Bowlby, S. and Gregory, S. (eds) Gender, Power and the Household, Basingstoke: Macmillan, pp.137-154.

Varner, G. (2002), 'Pets, companion animals and domesticated partners', in Benatar, D. (ed) Ethics for everyday, New York: McGraw Hill, pp.450-475.

Walsh, F. (2009), “Human-animal bonds II: The role of pets in family systems and family therapy", Family Process, Vol. 48 no. 4, pp.481-99.

Westgarth, C., Pinchbeck, G., Bradshaw, J.S.W, Dawson, S., Gaskell, R.M. and Christley, R.M. (2007), “Factors associated with dog ownership and contact with dogs in a UK community", BMC Veterinary Research 2007, Vol.3 No.5, available at: http://www.biomedcentral.com/1746-6148/3/5.

\footnotetext{
i Throughout I use the terms owner(s) and ownership as this is the way those living with dog companions describe themselves and others, and an accurate reflection of the legal status of dog companions in the UK who are essentially property with limited welfare secured in law.

ii This not to suggest Ingold has rejected human exceptionalism. When it comes to home making, only human beings are 'the authors of their own designs' (2012: 175)
} 